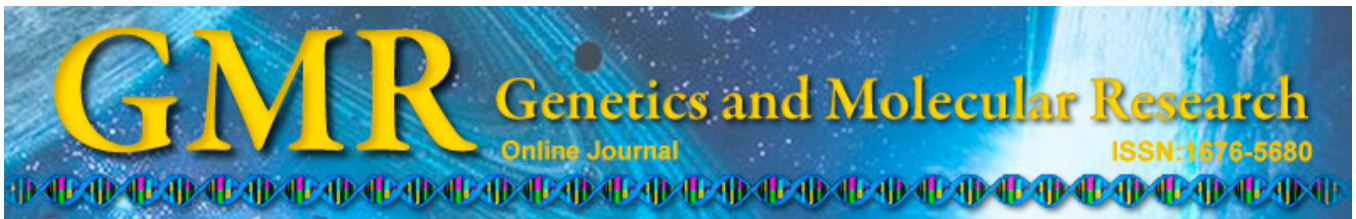

\title{
Antimutagenic action of the triterpene betulinic acid isolated from Scoparia dulcis (Scrophulariaceae)
}

\author{
P.L. de Freitas, A.C.S. Dias, V.R. Moreira, S.G. Monteiro and S.R.F. Pereira \\ Laboratório de Genética e Biologia Molecular, Departamento de Biologia, \\ Universidade Federal do Maranhão, São Luís, MA, Brasil \\ Corresponding author: S.R.F. Pereira \\ E-mail: silmaregina@yahoo.com.br
}

Genet. Mol. Res. 14 (3): 9745-9752 (2015)

Received January 30, 2015

Accepted June 8, 2015

Published August 19, 2015

DOI http://dx.doi.org/10.4238/2015.August.19.7

\begin{abstract}
The mutagenic and antimutagenic activities of triterpene betulinic acid \{3 $\beta$-3-hydroxy-lup-20(29)-en-28-oic $\}$ isolated from the roots of Scoparia dulcis (Scrophulariaceae) were analyzed using the somatic mutation and recombination test (SMART) in the wings of Drosophila melanogaster. The mutagenic potential of betulinic acid was evaluated at 3 different concentrations $(1.64,3.28$, and $6.57 \mathrm{mM})$. Antimutagenic activity evaluation was performed by co-treatment trials in which the flies received betulinic acid at 3 different concentrations in addition to $10 \mathrm{mM}$ pro-mutagenic urethane. The results demonstrated that betulinic acid was not capable of causing DNA damage. However, the frequency of small single spots, large spots, and twin spots was significantly reduced. In the high bioactivation cross, betulinic acid was significantly active and exerted enhanced antimutagenic activity, possibly as a desmutagen.
\end{abstract}

Key words: Antimutagenicity; Betulinic acid; Mutagenicity; Somatic mutation and recombination test; Triterpene 


\section{INTRODUCTION}

Several species of plants are used to treat diseases, raising the interest of researchers and the pharmaceutical industry. Some substances present in food and vegetables can cause damage to DNA and failures in DNA repair. These events may become fixed, and mutations can promote tumor development (McKenna et al., 2008).

Natural products play an important role in the discovery of anticancer drugs. More than $60 \%$ of anticancer drugs are of natural origin (Pagno et al., 2006; Santos et al., 2008). Betulinic acid is a pentacyclic triterpene found in several plant species that are widely distributed in the tropics, including Scoparia dulcis. A variety of biological properties have been attributed to this betulinic acid, such as a broad spectrum of cytotoxic activities against cancer cell lines (Kumar, 2008). Other studies have described its anti-human immunodeficiency virus activity (Singh et al., 2002; Pavlova et al., 2003) as well as its antiparasitic, antibacterial, and anti-inflammatory effects (Eiznhamer and $\mathrm{Xu}, 2004$ ). However, the mutagenic potential of this substance remains largely uncharacterized, although this potential is critical for its possible utilization as a pharmaceutical agent. Thus, we evaluated the mutagenic and antimutagenic activities of betulinic acid using the somatic mutation and recombination test (SMART) in Drosophila melanogaster wings.

\section{MATERIAL AND METHODS}

\section{Chemical agent}

Betulinic acid \{3ß-3-hydroxy-lup-20(29)-en-28-oic $\}$ was extracted and isolated from the roots of $S$. dulcis. The compound was extracted by routine phytochemical methods using organic solvents and subsequently isolated and purified by crystallization and recrystallization techniques. The compound was identified by physical organic analysis methods (infrared spectroscopy, ${ }^{1} \mathrm{H}$-nuclear magnetic resonance, ${ }^{13} \mathrm{C}$-nuclear magnetic resonance, distortionless enhancement by polarization transfer, and ${ }^{1} \mathrm{H}-{ }^{13} \mathrm{C}$-nuclear magnetic resonance correlation spectroscopy), and the degree of purity was evaluated by hydrogen nuclear magnetic resonance and found to be $96 \%$.

\section{Preparation of the applied solutions}

To determine the concentrations to be tested, pilot tests were performed to evaluate the compound's toxicity. Three different concentrations of betulinic acid were established $(1.64,3.28$, and $6.57 \mathrm{mM})$ to evaluate its mutagenicity. Urethane [URE, ethyl carbamate, $\mathrm{NH}_{2} \mathrm{COOCH}_{2} \mathrm{CH}_{3}$; (CAS \#51-79-6); Fluka, Buchs, Switzerland] was used as a positive control because of its dose-dependent genotoxic effects. This compound was used as a positive control in both the standard and high bioactivation crosses in D. melanogaster wings (Frölich and Würgler, 1990). Distilled water was used as a negative control.

\section{Lineages and crosses}

The SMART in D. melanogaster allows for the detection of several genotoxic events in the $\left(\mathrm{F}_{1}\right)$ generation based on phenotypic expression of the genetic markers multiple wing 
hairs ( $m w h, 3-0,3)$ and flare ( $\left.\operatorname{lr}^{3}, 3-38,8\right)$, which are located on chromosome 3 of cells from the imaginal disc of the wing in D. melanogaster larvae. These cells are visible on the wing surface of the adult fly. The test is based on the principle of loss of heterozygosity for these markers (Guzmán-Rincón and Graf, 1995).

Two crosses were performed. In the first standard (ST) cross, virgin $\mathrm{flr}^{3} / \mathrm{In}(3 \mathrm{LR})$ TM3,ri $\mathrm{p}^{\mathrm{p}}$ sep I(3)89Aa bx ${ }^{34 \mathrm{e}}$ and $\mathrm{Bd}^{\mathrm{s}}$ females were crossed with mwh/mwh males (Graf, 1995). In the 2nd high bioactivation (HB) cross, virgin ORR/ORR; $\mathrm{fl}^{3} / \operatorname{In}(3 \mathrm{LR}) \mathrm{TM} 3$, $\mathrm{ri}^{\mathrm{p}}$ sep $\mathrm{I}(3) 89 \mathrm{Aa} \mathrm{bx}^{34 \mathrm{e}}$ and $\mathrm{Bd}^{\mathrm{s}}$ females were crossed with $\mathrm{mwh} / \mathrm{mwh}$ males (Graf and van Schaik, 1992). The Oregon R (ORR) lineage is sensitive because this lineage contains chromosomes 1 and 2 from the Oregon $(\mathrm{R})$ lineage, which is resistant to dichlorodiphenyltrichloroethane, providing this lineage with high constitutive expression of the cytochrome P (CYP6A2) enzyme (Hällstrom and Blanck, 1985).

Two types of descendants were derived from both crosses, the marked transheterozygotes and balanced heterozygotes. The descendants were phenotypically distinct based on the $\mathrm{TM} 3, \mathrm{Bd}^{\mathrm{s}}$ marker. Adult marked transheterozygote flies $\left(\mathrm{mwh}+/+\mathrm{flr}^{3}\right)$ had normal wings with smooth edges. In contrast, balanced heterozygote flies $\left(\mathrm{mwh}+/+\mathrm{TM}^{3}, \mathrm{Bd}^{\mathrm{s}}\right)$ had wings with jagged edges, called serrate, because they carried a balanced chromosome with multiple inversions and a dominant marker ( $\left.\mathrm{TM}^{3}, \mathrm{Bd}^{\mathrm{s}}\right)$ (Guzmán-Rincón and Graf, 1995). Comparison between the frequencies of spots observed in the descendants of these 2 genotypes allowed for quantification of the recombinogenic action of the tested agent (Lehmann et al., 2003).

\section{Larva treatment}

Larvae from the ST and HB crosses were handled in parallel under the same conditions. Eggs from these 2 crosses were collected $8 \mathrm{~h}$ after oviposition in flasks containing $4 \%$ $(\mathrm{w} / \mathrm{v})$ solid agar base, covered with a layer of medium prepared from yeast enriched with sugar. After 3 days, the larvae were transferred to flasks containing $1.5 \mathrm{~g}$ instant medium (Carolina Supply, Burlington, NC, USA) and $5 \mathrm{~mL}$ test compound. Negative and positive controls were included. The larvae reached the pupal stage by $48 \mathrm{~h}$.

\section{Wing analysis}

After metamorphosis, adult flies were collected and placed in flasks containing $70 \%$ ethanol. The pairs of wings were detached, mounted on glass microscope slides in Faure solution, and analyzed at 400X magnification. On the wings of the marked transheterozygote descendants, 2 types of spots were observed, the type 1 - simple $\left(\mathrm{mwh}\right.$ or $\left.\mathrm{flr}^{3}\right)$, of which the mwh were the most frequently observed and produced by point mutations, recombination, or chromosomal aberration, and type 2 - twins (multiple adjacent hair and flare hair), which were produced exclusively by somatic recombination. In the balanced heterozygote descendants, it was only possible to detect mutational events because the balanced chromosome contained multiple inversions, and thus the products of mitotic recombination were not viable (Graf et al., 1984; Graf and Van Schaik, 1992; Frei and Würgler, 1996).

\section{Statistical analysis}

Statistical analyses of the mutagenicity and antimutagenicity data were performed 
based on the frequency of each type of spot per individual. The treatments were compared using the non-parametric Mann-Whitney U-test. In the mutagenicity study, the data were compared to the negative control, while in the antimutagenicity study, the co-treatment data were compared to the positive control.

\section{RESULTS}

The mutagenic potential of betulinic acid was evaluated using chronic treatment in the ST and HB crosses. The spontaneous frequencies of spots per wing in the negative control group were 1.41 spots per wing in ST and 2.17 spots per wing in HB. In the positive control group, the frequencies were 2.47 spots per wing in ST and 12.34 spots per wing in HB. In both crossing methods, there was no significant difference between the groups treated with betulinic acid $(1.64,3.28$, and $6.57 \mathrm{mM})$ and the negative control. In both crosses, there was a significant increase in the frequency of spots in the positive control, with greater induction in the high bioactivation method $(\mathrm{P}<0.001$; Table 1$)$.

Table 1. Results for mutagenicity of betulinic acid in standard and high bioactivity crosses.

\begin{tabular}{|c|c|c|c|c|c|c|c|c|c|c|}
\hline \multirow[t]{2}{*}{ MUT } & \multirow[t]{2}{*}{$\begin{array}{c}\mathrm{BA} \\
(\mathrm{mM})\end{array}$} & \multirow[t]{2}{*}{$\mathrm{N}$} & \multicolumn{4}{|c|}{$\begin{array}{l}\text { Spot frequency per individual } \\
\text { (number of spots) statistical diagnosis } \\
\text { by Mann-Whitney U-test }\end{array}$} & \multirow[t]{2}{*}{$\operatorname{mwh}^{\mathrm{b}}(n)$} & \multirow[t]{2}{*}{$\begin{array}{l}\text { Mean size } \\
\operatorname{mwh}^{\mathrm{b}, \mathrm{c}}(\hat{\imath})\end{array}$} & \multicolumn{2}{|c|}{$\begin{array}{l}\text { Frequency of spot induction } \\
\quad\left(\text { per } 10^{5} \text { cell divisions) }\right)^{\mathrm{e}}\end{array}$} \\
\hline & & & $\begin{array}{c}\text { SSS } \\
(1-2 \text { cells })^{\mathrm{a}}\end{array}$ & $\begin{array}{l}\text { LSS } \\
(>2 \text { cells })^{\mathrm{a}}\end{array}$ & TS & $\begin{array}{l}\text { Total } \\
\text { spots }\end{array}$ & & & $\begin{array}{l}\text { Not corrected } \\
\text { for size } \mathrm{e}^{\mathrm{c}, \mathrm{d}} \\
(n / N C)\end{array}$ & $\begin{array}{c}\text { Corrected } \\
\text { for size } \mathrm{e}^{\mathrm{c}, \mathrm{d}} \\
\left(2^{\mathrm{i}-2}\right) \times(n / N C)\end{array}$ \\
\hline \multicolumn{11}{|c|}{ Standard } \\
\hline 0 & 0 & 29 & $0.59(17)$ & $0.07(2)$ & $0.07(2)$ & $0.72(21)$ & 20 & 1.55 & 1.41 & 1.03 \\
\hline 0 & 1.64 & 30 & $0.37(11)^{\mathrm{ns}}$ & $0.03(1)^{\mathrm{ns}}$ & $0.00(0)^{\mathrm{ns}}$ & $0.40(12)^{\mathrm{ns}}$ & 12 & $1.50(1.62)$ & $0.82(0.59)$ & $0.58(0.46)$ \\
\hline 0 & 3.28 & 18 & $0.56(10)^{\mathrm{ns}}$ & $0.11(2)^{\mathrm{ns}}$ & $0.00(0)^{\mathrm{ns}}$ & $0.67(12)^{\mathrm{ns}}$ & 12 & $2.17(16.33)$ & $1.37(0.05)$ & $1.53(0.50)$ \\
\hline 0 & 6.57 & 38 & $0.29(11)^{\mathrm{ns}}$ & $0.05(2)^{\mathrm{ns}}$ & $0.03(1)^{\mathrm{ns}}$ & $0.37(14)^{\mathrm{ns}}$ & 14 & $1.50(1.61)$ & $0.75(0.66)$ & $0.53(0.50)$ \\
\hline 10 & 0 & 29 & $1.07(31)^{*}$ & $0.17(5)^{\mathrm{ns}}$ & $0.03(1)^{\mathrm{ns}}$ & $1.28(37)^{*}$ & 35 & $1.57(1.60)$ & $2.47(1.01)$ & $1.84(0.77)$ \\
\hline \multicolumn{11}{|c|}{ High bioactivity } \\
\hline 0 & 0 & 50 & $0.92(46)$ & $0.08(4)$ & $0.02(1)$ & $1.02(51)$ & 53 & 1.6 & 2.17 & 1.65 \\
\hline 0 & 1.64 & 29 & $0.79(23)^{\mathrm{ns}}$ & $0.14(4)^{\mathrm{ns}}$ & $0.00(0)^{\mathrm{ns}}$ & $0.93(27)^{\mathrm{ns}}$ & 27 & $1.78(0.35)$ & $1.91(0.26)$ & $1.64(0.08)$ \\
\hline 0 & 3.28 & 37 & $0.65(24)^{\mathrm{ns}}$ & $0.05(2)^{\mathrm{ns}}$ & $0.05(2)^{\mathrm{ns}}$ & $0.76(28)^{\mathrm{ns}}$ & 26 & $1.81(1.20)$ & $1.44(0.73)$ & $1.26(0.42)$ \\
\hline 0 & 6.57 & 41 & $0.51(21)^{\mathrm{ns}}$ & $0.02(1)^{\mathrm{ns}}$ & $0.05(1)^{\mathrm{ns}}$ & $0.56(23)^{\mathrm{ns}}$ & 23 & $1.39(1.84)$ & $1.15(1.02)$ & $0.75(0.92)$ \\
\hline 10 & 0 & 44 & $4.84(213) * *$ & $* 1.09(48)^{* *}$ & $0.05(22)^{* *}$ & $6.43(283)^{* * *}$ & 265 & $1.95(2.03)$ & $12.34(10.66)$ & $11.96(10.88)$ \\
\hline
\end{tabular}

In the antimutagenicity test, flies were co-treated with betulinic acid and URE in the ST and HB crosses. Treatments were performed simultaneously under the same conditions. In the ST cross, there was no significant difference between the groups co-treated at concentrations of 3.28 and $6.57 \mathrm{mM}$ and the positive control (Table 1), indicating that at these concentrations, betulinic acid did not reduce the frequency of URE-induced spots. However, treatment with the $1.64 \mathrm{mM}$ betulinic acid was significantly different from the positive control and led to a greater number of simple spots. In the HB cross, betulinic acid significantly reduced the frequency of small simple spots, large spots, and twin spots at all 3 concentrations (Table 2 ). The inhibition potential of betulinic acid was $65.5,75$, and $84.3 \%$ at concentrations of 1.64 , 3.28 , and $6.57 \mathrm{mM}$, respectively. 
Antimutagenic action of the triterpene betulinic acid

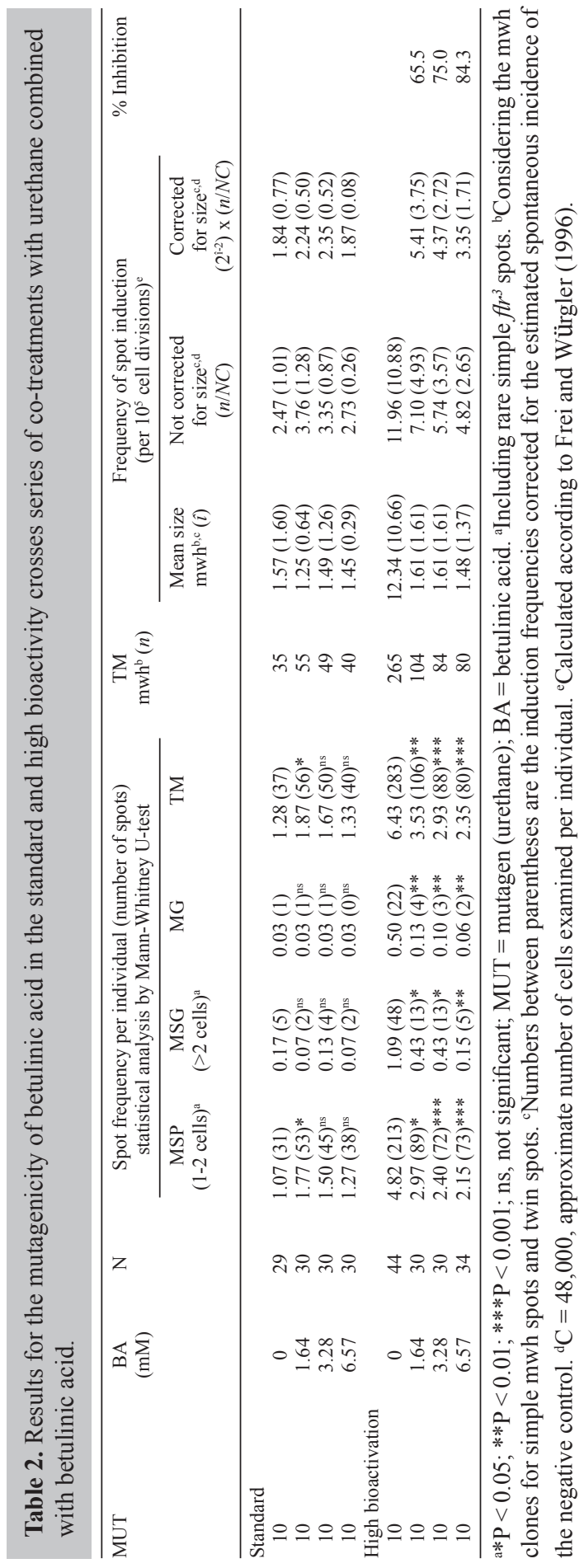




\section{DISCUSSION}

Betulinic acid has been reported to be an antineoplastic agent with specificity for the neuroectoderm. It is capable of inducing apoptosis in neuroblastoma cells resistant to doxorubicin as well as in primary tumor cultures of neuroectodermal origin (Raghuvar et al., 2004; Subramanyam et al., 2009). Moreover, betulinic acid was active against medulloblastoma and glioblastoma cell lines and against tumor cells isolated from patients with medulloblastoma and glioblastoma, but not cytotoxic against mouse neurons in vitro (Fulda et al., 1999).

In the present study, the mutagenic and antimutagenic potential of the triterpene betulinic acid was evaluated by the SMART in D. melanogaster. The advantages of this test have been widely demonstrated in several studies (Santos et al., 1999; Vogel et al., 1999; Cunha et al., 2001; Tiburi et al., 2002; De Boeck et al., 2003; Munerato et al., 2005).

The data obtained in this study in the negative and positive control groups, which were treated with water and URE, respectively, were consistent with the data reported in previous studies (Frei and Würgler, 1996; Campesato et al., 1997). URE genotoxicity in D. melanogaster was demonstrated for the first time by Oster (1995), who reported the induction of sexlinked recessive lethality after adult male exposure, and by Ahmed and Walker (1975), who demonstrated the induction of gene permutation by URE, which affected DNA after enzymatic metabolism, leading to the formation of vinyl carbamate and after epoxidation in DNA adducts (Gupta and Dani,1989).

The data obtained from both crosses in the present study indicate that the genetic basis of the lineages used in both the ST and HB crosses does not interfere with the spontaneous level of mutant clones. The test conducted to evaluate the mutagenic potential of betulinic acid at the evaluated concentrations did not lead to a significant difference $(\mathrm{P}>0.05)$, indicating that this compound did not cause direct or indirect DNA damage. However, all 3 concentrations of betulinic acid reduced the frequency of all types of spots induced by URE in the HB cross. Thus, betulinic acid is capable of reversing the genotoxic effect of URE in lineages with high metabolic power.

Based on our results, betulinic acid may be a desmutagen. This can be explained by the fact that the $O R R / f r^{3}$ lineage used in this cross showed a high capacity to metabolize xenobiotic substances because of the high levels of cytochrome P-450 enzymes in this lineage. The $\mathrm{fl}^{3}$ lineage contains only a basal level of these enzymes (Hällstrom and Blanck, 1985). This feature explains why the pro-mutagen URE had mutagenic activity in the standard crossing.

Other studies have demonstrated that triterpenes exhibit antimutagenic activity in vivo. Chen et al. (2002) reported the chemopreventive potential of this compound based on its ability to inhibit superoxide production in leukocytes under induced oxidative stress. This antioxidant activity may be related to antitumor activity, as suggested most recently by Ovesná et al. (2006). These authors showed that triterpenes can inhibit DNA strand breaks induced by hydrogen peroxide in leukemic cells.

Aparecida Resende et al. (2006) demonstrated the antigenotoxic activity in micronucleated polychromatic erythrocytes induced by doxorubicin in mice, possibly through antioxidant activity. Other studies have indicated that triterpenes protect DNA from oxidative damage caused by $\mathrm{H}_{2} \mathrm{O}_{2}$ and activate the base excision repair system (Ramos and Pereira-Wilson, 2010). A study by Ehrhardt et al. (2004) reported the induction of apoptosis in leukemic tumor cells, and Raghuvar et al. (2004) describe the ability of betulinic acid to induce apoptosis in sarcoma cells. Thus, pentacyclic triterpenes have been described as being among the com- 
pounds with great anticancer activity; this group also includes ursolic acid, oleanolic acid, and lupeol (Lopes et al., 2005).

In conclusion, the antimutagenic effects of betulinic acid against genetic damage induced by URE at the 3 concentrations tested were consistent with the results of studies reporting the antitumor and antioxidant activity of triterpenes.

\section{ACKNOWLEDGMENTS}

Research supported by the Foundation for the Support of Research and Technology Advancement of Maranhão.

\section{REFERENCES}

Ahmed ZU and Walker GW (1975). The effects of urethane, sodium monohydrogen arsenate and selenocysteine on crossing over in Drosophila melanogaster. Can. J. Genet. Cytol. 17: 55-66.

Aparecida Resende F, de Andrade Barcala CA, da Silva Faria MC, Kato FH, et al. (2006). Antimutagenicity of ursolic acid and oleanolic acid against doxorubicin-induced clastogenesis in Balb/c mice. Life Sci. 79: 1268-1273.

Campesato VR, Graf U, Reguly ML and de Andrade HHR (1997). Recombinagenic activity of integerrimine, a pyrrolizidine alkaloid from Senecio brasiliensis in somatic cells of Drosophila melanogaster. Environ. Mol. Mutagen. 29: 91-97.

Chen G, Lu H, Wang C, Yamashita K, et al. (2002). Effect of five triterpenoid compounds isolated from leaves of Diospyros kaki on stimulus-induced superoxide generation and tyrosyl phosphorylation in human polymorphonuclear leukocytes. Clin. Chim. Acta 320: 11-16.

Cunha KS, Reguly ML, Graf U and de Andrade HHR (2001). Taxanes: the genetic toxicity of paclitaxel and docetaxel in somatic cells of Drosophila melanogaster. Mutagenesis 16: 79-84.

De Boeck M, Kirsch-Volders M and Lison D (2003). Cobalt and antimony: genotoxicity and carcinogenicity. Mutat. Res. 533: 135-152.

Ehrhardt H, Fulda S, Fuhrer M, Debatin KM, et al. (2004). Betulinic acid induced apoptosis in leukemia cells. Leukemia 18: 1406-1412.

Eiznhamer DA and Xu ZQ (2004). Betulinic acid: A promising anticancer candidate. IDrugs 4: 359-373.

Frei H and Würgler FE (1996). Induction of somatic mutation and recombination by four inhibitors of eukaryotic topoisomerases assayed in the wing spot test of Drosophila melanogaster. Mutagenesis 11:315-325.

Frölich A and Würgler FE (1990). Drosophila wing spot test: Improved detectability of genotoxicity of polycyclic aromatic hydrocarbons. Mutat. Res. 234: 71-80.

Fulda S, Jeremias I, Pietsch T and Debatin KM (1999). Betulinic acid: A new chemotherapeutic agent in the treatment of neuroectodermal tumors. Klin. Padiatr. 211: 319-322.

Graf U (1995). Analysis of the relationship between age of larvae at mutagen treatment and frequency and size of spots in the wing somatic mutation and recombination test of Drosophila melanogaster. Experientia 51: 168-173.

Graf U and Van Schaik N (1992). Improved high bioactivation cross for the wing somatic mutation and recombination test in Drosophila melanogaster. Mutat. Res. 271: 59-67.

Graf U, Würgler FE, Katz AJ, Frei H, et al. (1984). Somatic mutation and recombination test in Drosophila melanogaster. Mutat. Res. 271: 59-67.

Gupta AP and Dani HM (1989). In vitro formation of organ specific ultimate carcinogens of 4-dimethylaminoazobenzene and urethane by microsomes. Toxicol. Lett. 45: 49-53.

Guzmán-Rincón J and Graf U (1995). Drosophila melanogaster somatic mutation and recombination test as a biomonitor. In: Biomonitors and biomarkers of environmental change (Butterworth FM, Corkum LD and Guzmán-Rincón J, eds.). A Handbook Plenum Press, New York, 169-181.

Hällstrom I and Blanck A (1985). Genetic regulation of the cytochrome P-450 system in Drosophila melanogaster I. Chromosomal determination of some cytochrome P-450 dependent reactions. Chem. Biol. Interact. 56: 157-171.

Kumar V, Rani N, Aggarwal P, Sanna VK, et al. (2008). Synthesis and cytotoxic activity of heterocyclic ring-substituted betulinic acid derivatives. Bioorg. Med. Chem. Lett. 18: 5058-5062.

Lehmann M, Franco A, De Sousa PVK, Lukza RM, et al. (2003). Doxorubicin and its analogues are preferential inducers of homologous recombination compared with mutational events in somatic cells of Drosophila melanogaster. Mutat. Res. 539: 175-176. 
Lopes FC, Calvo TR, Vilegas W and Carlos IZ (2005). Inhibition of hydrogen peroxide, nitric oxide and TNF- $\alpha$ production in peritoneal macrophages by ethyl acetate fraction from Alchornea glandulosa. Biol. Pharm. Bull. 28: 1726-1730.

McKenna DJ, McKeown SR and McKelvey-Martin VJ (2008). Potential use of the comet assay in the clinical management of cancer. Mutagenesis 23: 183-194.

Munerato MC, Sinigaglia M, Reguly ML and de Andrade HHR (2005). Genotoxic effects of eugenol, isoeugenol and safrole in the wing spot test of Drosophila melanogaster. Mutat. Res. 582: 87-94.

Oster II (1995). The induction of mutations in Drosophila melanogaster by orally administered ethyl carbamate (urethane). Genetics 40: 588-589.

Ovesná Z, Kozics K and Slamenová D (2006). Protective effects of ursolic acid and oleanolic acid in leukemic cells. Mutat. Res. 600: 131-137.

Pagno T, Blind LZ, Biavatti MW and Kreuger MRO (2006). Cytotoxic activity of the dichloromethane fraction from Vernonia scorpioides (Lam.) Pers. (Asteraceae) against Ehrlich's tumor cells in mice. Braz. J. Med. Biol. Res. 39: 1483-1491.

Pavlova NI, Savinova OV, Nikolaeva SN, Boreko EI, et al. (2003). Antiviral activity of betulin, betulinic and betulonic acids against some enveloped and non-enveloped viruses. Fitoterapia 74: 489-492.

Raghuvar Gopal DV, Narkar AA, Badrinath Y, Mishra KP, et al. (2004). Protection of Ewing's sarcoma family tumor (ESFT) cell line SK-N-MC from betulinic acid induced apoptosis by $\alpha$-DL-tocopherol. Toxicol. Lett. 153: 201-212.

Ramos AA and Pereira-Wilson C (2010). DNA damage include enhancement of DNA repair in Caco-2 cells. Mutat. Res. 692: 6-11.

Santos FV, Tubaldini FR, Cólus IM, Andréo MA, et al. (2008). Mutagenicity of Mouriri pusa Gardner and Mouriri elliptica Martius. Food Chem. Toxicol. 46: 2721-2727.

Santos JH, Graf U, Reguly ML and Rodrigues de Andrade HH (1999). The synergistic effects of vanillin on recombination predominate over its antimutagenic action in relation to MMC-induced lesions in somatic cells of Drosophila melanogaster. Mutat. Res. 444: 355-365.

Singh SS, Patro B, Tripathi V, Srivastava A, et al. (2002). Betulinic acid and its pharmacological activity. Med. Arom. Plant Sci. 24: 1031-1037.

Subramanyam R, Gollapudi A, Bonigala P, Chinnaboina M, et al. (2009). Betulinic acid binding to human serum albumin: A study of protein conformation and binding affinity. J. Photochem. Photobiol. B 94: 8-12.

Tiburi M, Reguly ML, Schawartsmann G, Cunha KS, et al. (2002). Comparative genotoxic effect of vincristine, vinblastine and vinorelbine in somatic cells of Drosophila melanogaster. Mutat. Res. 51: 141-149.

Vogel EW, Graf U, Frei H and Nivard MMJ (1999). The results of assays in Drosophila as indicators of exposure to carcinogen. In: The use of short- and medium-term tests for carcinogens and data on genetic effects in carcinogens hazard evaluation (McGregor DB, Rice JM and Venitt S, eds.). IARC Scientific Publication, Lyon, 427-470. 